\title{
Statistical agreement between ATPIII, IDF, EGIR, AACE metabolic syndrome classifications in HIV-infected patients and association with lipodystrophy

\author{
G Guaraldi*, S Zona, R D'Amico, N Squillace, G Orlando, C Stentarelli and \\ R Esposito
}

Address: University of Modena and Reggio Emilia, Modena, Italy

* Corresponding author

from Ninth International Congress on Drug Therapy in HIV Infection

Glasgow, UK. 9-13 November 2008

Published: 10 November 2008

Journal of the International AIDS Society 2008, I I (SuppI I):PI25 doi:10.I I86/I758-2652-I I-SI-PI 25

This abstract is available from: http://www.jiasociety.org/content/I I/SI/PI 25

(C) 2008 Guaraldi et al; licensee BioMed Central Ltd.

\section{Purpose of the study}

To assess statistical agreement of metabolic syndrome (MS) ATPIII, IDF, EGIR and AACE classification in HIVinfected patients and association with body fat redistribution.

\section{Methods}

Cross-sectional observational study that included all consecutive HIV-infected patients seen at a metabolic clinic who were screened for MS and had a clinical and radiological lipodystrophy (LD) evaluation. Cohen's Kappa statistic was calculated to assess statistical agreement between different MS classifications. Logistic regression models were performed to identify factors associated with different MS classifications. (Tables 1 and 2.)

\section{Summary of results}

1,348 pts were included in the analysis.

Figure 1 depicts prevalence of metabolic syndrome according to different definition.

\section{Conclusion}

Concordance between MS classification is less than ideal. After adjusting for BMI strata, lipodystrophy phenotypes and central fat accumulation are associated with for MS diagnosis.
Table I: $K$ of Cohen shows a low level of agreement between MS classifications.

\begin{tabular}{llll}
\hline & EGIR & AACE & NCEP ATP-III \\
\hline IDF & $0.27 *(64.61 \%)$ & $0.07 *(56.01 \%)$ & $0.41 *(71.66 \%)$ \\
EGIR & & $0.21 *(74.33 \%)$ & $0.38^{*}(75.74 \%)$ \\
AACE & & & $0.35^{*}(81.68 \%)$ \\
\hline
\end{tabular}


anthropometric variables) were included in univariable and multivariable logistic analysis. 
Table 2:

\begin{tabular}{|c|c|c|c|c|c|c|}
\hline Variables & ATP-III Adj. OR (95\% Cl) & P-value & EGIR Adj. OR (95\% Cl) & P-value & IDF Adj. OR (95\% Cl) & P-value \\
\hline Lipoatrophy & $1.14(0.66 ; 1.96)$ & 0.63 & $1.20(0.7 \mathrm{I} ; 2.03)$ & 0.49 & $1.21(0.79 ; 1.84)$ & 0.37 \\
\hline Central adiposity & $1.87(0.99 ; 3.53)$ & 0.054 & $2.88(1.64 ; 4.27)$ & 0.001 & $2.14(1.21 ; 3.79)$ & 0.009 \\
\hline Mixed form & $2.06(1.26 ; 3.37)$ & 0.004 & $2.65(1.64 ; 4.27)$ & $<0.0001$ & $2.12(1.43 ; 3.14)$ & $<0.0001$ \\
\hline$\%$ fat legs $(10 \%)$ & $1.04(0.82 ; 1.32)$ & 0.73 & $0.73(0.57 ; 0.93)$ & 0.013 & $0.91(0.74 ; 1.13)$ & 0.41 \\
\hline VAT/TAT & $12.35(4.84 ; 31.48)$ & $<0.0001$ & $2.80(1.16 ; 6.78)$ & 0.022 & $2.37(1.08 ; 5.21)$ & 0.031 \\
\hline \multicolumn{7}{|l|}{ BMI } \\
\hline$<19$ & $0.33(0.13 ; 0.86)$ & 0.024 & $0.30(0.12 ; 0.78)$ & 0.014 & $0.51(0.28 ; 0.92)$ & 0.027 \\
\hline between 19 and 25 & Ref. & - & Ref. & - & Ref. & - \\
\hline between 25 and 30 & $2.12(1.51 ; 2.99)$ & $<0.0001$ & $2.36(1.70 ; 3.28)$ & $<0.0001$ & $2.42(1.76 ; 3.32)$ & $<0.0001$ \\
\hline$>30$ & $5.56(3.04 ; 10.16)$ & $<0.0001$ & $12.38(6.28 ; 24.43)$ & $<0.0001$ & $5.99(3.02 ; 11.90)$ & $<0.0001$ \\
\hline
\end{tabular}

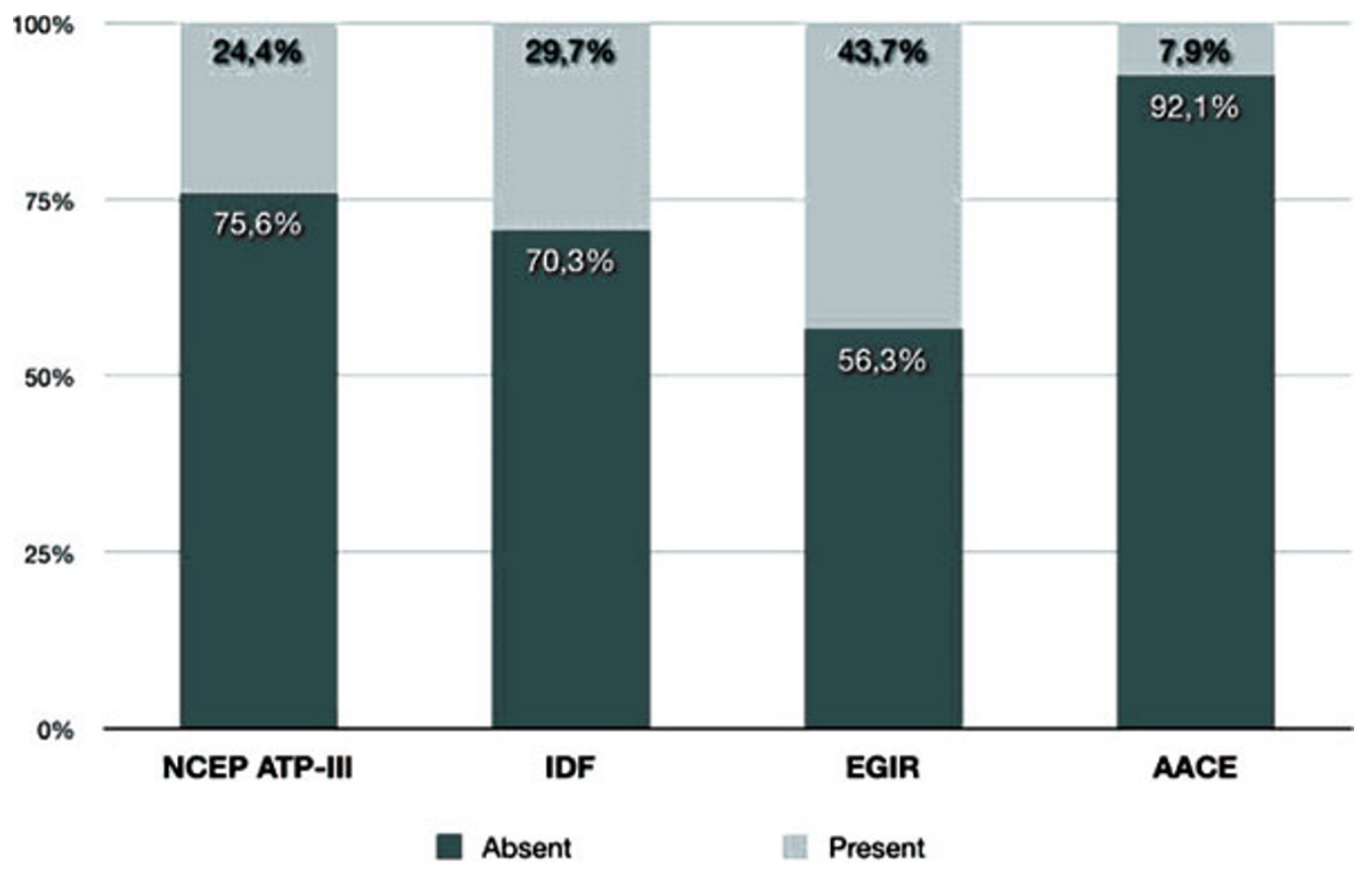

Figure I

Publish with Biomed Central and every scientist can read your work free of charge

"BioMed Central will be the most significant development for disseminating the results of biomedical research in our lifetime. "

Sir Paul Nurse, Cancer Research UK

Your research papers will be:

- available free of charge to the entire biomedical community

- peer reviewed and published immediately upon acceptance

- cited in PubMed and archived on PubMed Central

- yours - you keep the copyright
BioMedcentral 